\title{
Algal polysaccharides as source of plant resistance inducers
}

\author{
Marciel J. Stadnik \& Mateus B. de Freitas \\ Laboratório de Fitopatologia, CCA, Universidade Federal de Santa Catarina, 88034-001, Florianópolis, SC, Brazil \\ Author for correspondence: Marciel J. Stadnik, e-mail: marciel.stadnik@ufsc.br
}

\begin{abstract}
Algal compounds exhibit great potential to enhance plant growth and resistance to abiotic and biotic stresses. This review focuses on aspects concerning the physical-chemical properties, function and biological activity of macroalgae polysaccharides. Updated results of the main poly- and oligosaccharides studied for the control of plant diseases are discussed and summarized. The carrageenans from red algae have a well-established obtaining system, but its high market value discourages its use in plant protection. The fucans found in the cell walls of brown algae are present in several fertilizers and accounted for the benefits of such commercial products on plant physiology. The laminarans, from brown algae mainly Laminaria digitata, are currently the main algal polysaccharides on the phytosanitary market. The ulvans, from cell the walls of Ulva spp., open new ways to obtain polysaccharides able to induce resistance due to its abundance worldwide. All these algal polysaccharides show ability to activate multiple plant defense mechanisms against a broad spectrum of plant pathogens. Taking into account the promising results reported in the literature and the enormous biochemical diversity of these biopolymers, it is likely that they will provide new types of resistance inducers in a near future.
\end{abstract}

Key words: Carrageenans, fucans, laminarans, ulvans.

\section{INTRODUCTION}

The seaweeds (macroalgae) are a diverse group of organisms that frequently occur in marine environment and usually grow fast and produce high biomass yields. These attributes turn its commercial exploitation attractive for variable purposes such as agriculture (Stadnik \& Paulert, 2008).

Almost $70 \%$ of the biosphere is covered by marine biomes, with a fantastic taxonomical and biochemical diversity. In this context, macroalgae show a great potential for generation of new agricultural technologies, attested by the success of already commercialized algae derived products (Kulik, 1995; Stadnik \& Paulert, 2008; Craige, 2011).

Besides their traditional use as organic fertilizers, algae have expressive biotechnological potential as a source of compounds that can stimulate plant growth and protect them against pathogens. Such applications have made feasible their rational exploitation, because they add market value to the product and use of small quantities per area (Stadnik \& Paulert, 2008; Khan et al., 2009).

As well as other marine organisms, macroalgae are source, little explored, of physiological stimulants and resistance elicitors to the cultivated plants. Considering the actual trends of market that looks for efficiency, human health and the environmental friendship, the demand of such products might increase. The algae and their polysaccharides are perfectly inserted in this scenario. Another advantage that favors the use of algae, as raw material to obtain polysaccharides and other bioactive molecules, is the benefit-cost analysis of investments in research and industrial production, which give high reward because the chemical synthesis of new molecules is not needed (Stadnik \& Paulert, 2008; Craige, 2011).

Without the intention of exhausting the topic, this review focuses on different aspects concerning the chemistry, physical-chemical properties and biological function of polysaccharides in the nature. In the sequence, results of the main studied poly- and oligosaccharides for the control of plant diseases are summarized.

\section{Polysaccharides structure and function}

Conceptually, polysaccharides, also known as glycans, are natural macromolecules (biopolymers) of joined monosaccharide units and, as a consequence, with a high molecular mass that is dependent of the number unities that compose it (Nelson \& Cox, 2008). Considering that the repeated units in the backbone of polymer are often six-carbon monosaccharides, the general formula can also be represented as $\left(\mathrm{C}_{6} \mathrm{H}_{10} \mathrm{O}_{5}\right)_{\mathrm{n}}$ where " $\mathrm{n}$ " stands between 20 and 3000. Conventionally, the polysaccharides contain more than 20 monosaccharides units such as glucose, fructose and glyceraldehyde. However, definitions of how large a carbohydrate must be to fall into the categories of polysaccharides or oligosaccharides are subjective. Anyway, these carbohydrates can be hydrolyzed in oligosaccharides, disaccharides or monosaccharides using chemical, physical or biochemical methods (Richter, 1996; Nelson \& Cox, 2008).

Polysaccharides exhibit a molecular structure that can be linear or highly branched, composed by the same 
(homopolysaccharide) or different (heteropolysaccharide) monosaccharide units. Structural differences confer distinct physical-chemical properties. For example, in water, they can be insoluble (such as cellulose) or soluble in gel form (such as pectin and alginate), showing viscoelastic properties. Several polysaccharides are acids due to the presence of carboxylic groups, phosphate groups and/or ester sulfuric in the molecular structure (Nelson \& Cox, 2008). In organisms, the polysaccharides are classified according to their biological function in two groups: energy storage and structural polysaccharides. When glucose is not acting in a metabolic pathway, it can be stored as reserve polysaccharide called starch in plants, glycogen in animals and laminaran in brown algae. Polysaccharides can also form organic structures such as cellulose, which is the most important and abundant in the nature, chitin, the main component of the cell walls of fungi and the agar of red algae. In contrast to chitin, chitosan is a water-soluble chitin derivative that acts as an elicitor of plant defense responses (Richter, 1996; Nelson \& Cox, 2008).

Besides the energetic reserves and structural functions, several poly and oligosaccharides exhibit different kind of biological activities. Some bacteria and others microorganisms, including fungi and microalgae, developed capsular adaptations by secreting polysaccharides that help their adhesion to surfaces and prevent the desiccation. These capsular polysaccharides, including peptidoglycans, lipopolysaccharides and exopolysaccharides, are water soluble, acids and participate in the host-pathogen interaction. As an example of great structural diversity of polysaccharides is the fact that just the bacterium Escherichia coli (Migula) Castellani and Chalmers is able to produce a dozen of complex polysaccharides (Whitfield, 2006).

\section{Algae polysaccharides}

Algae polysaccharides are probably the most abundant organic molecules in the oceans and have a great molecular biodiversity that is far from being understood (Kloareg \& Quatrano 1988). In the last decades, studies revealed the enormous potential of these macromolecules as elicitors of plants defense responses (Klarzynski et al., 2000; Mercier et al., 2001; Patier et al., 1995). Aspects and advances related with the use of the most studied macroalgae polysaccharides such as carrageenans, fucans, laminarans and ulvans to protect plants will be discussed.

\section{Carrageenans}

The carrageenans have been used, for hundreds of years, as additives in several industrial processes and food products, mainly as stabilizers, gelling agents, thickeners and clarifiers of beverages. Due to its high value, seaweeds containing carrageenans have been extensively cultivated in sea farming (Bixler, 1996). Carrageenans are extracted from red algae (Rodophyta), mainly from Kappaphycus alvarezii (Doty) Doty ex Silva, grown in Philippines. The
$K$. alvarezii was recently introduced in Brazil for rational cultivation (Hayashi et al., 2011). Before its introduction, there were attempts to Hypnea musciformis (Wulfen) Lamouroux cultivation, a naturally found species in the Brazilian coast, with little success (Hayashi et al, 2007). Besides the advantage of a well-established system for carrageenans production, the great demand to attend current needs, the high market value will possibly be a constraint for its use in agriculture.

Carrageenans, also known as sulfated galactans, are linear polysaccharides and composed by repeating dimmers of $\alpha-1,4-D$-galactose, which are linked by alternated bonds of $\alpha-1,3$ and $\beta-1,4$ and substituted by one ( $\kappa$-carrageenan), two (1-carrageenan) or three $(\lambda$-carrageenan) sulfate ester groups within each repeating unit (Figure 1). In commercial preparations, $\kappa$-, 1 - and $\lambda$ - carrageenans exhibit high contents of sulfate, i.e., $22 \%, 32 \%$ and $38 \%(\mathrm{p} / \mathrm{p})$, respectively and different physical-chemical properties (De Ruiter \& Rudolf, 1997; Sangha et al., 2010). An interesting fact is that the carrageenans ratio, found in red algae, vary according to the algae species. For example, $K$. alvarezii and $H$. musciformis have more $\kappa$-carrageenan, while Eucheuma denticulatum (Burman) Collins and Hervey and Gigartina pistillata (Gmelin) Stackhouse have more 1-carrageenan and $\lambda$-carrageenan, respectively (Bixler, 1996; De Ruiter \& Rudolph, 1997).

The defense system of plants can be activated by the application of carrageenans and its oligosaccharides. Patier et al. (1995) found that the $\kappa$-carrageenan elicited the activity of $\beta-1,3$-glucanase in cell cultures of Rubus fruticosus $\mathrm{L}$. and that the oligo- $\kappa$-carrageenans were more efficient than the original polysaccharide. In tobacco plants, Mercier et al. (2001) observed that the application of carrageenan triggered different defense systems involving ethylene, jasmonic acid and salicylic acid pathways. On the other hand, Sangha et al. (2010) demonstrated that the induction of resistance by $\lambda$-carrageenan in Arabidopsis thaliana (L.) Heynhold against Sclerotinia sclerotiorum (Libert) de Bary was due to an increase in oxalate oxidase activity and is related with the expression of jasmonic acid signaling associated genes, e.g., AOS, PDF1.2 and PR3. In addition, $\lambda$-carrageenan was able to induce resistance in a salicylic acid deficient mutant of $A$. thaliana (ics 1 ), suggesting that the resistance induction was independent of this pathway.

Carrageenans and their oligosaccharides can activate defense mechanisms against plant pathogens including bacteria, fungi and virus. Recently, Vera et al. (2012) demonstrated the systemic effect of $\kappa-$, 1 - and $\lambda$-oligo-carrageenans against tobacco mosaic virus (TMV), Botrytis cinerea Persoon and Pectobacterium carotovorum (Jones) Waldee. In this study, higher concentrations and frequent applications of oligo-carrageenans $(1-5 \mathrm{mg} / \mathrm{mL})$, mainly $\lambda$-oligo-carrageenan resulted in a durable protection of plants against TMV. In addition, the treatment with oligo-carrageenans increased the phenylalanine ammonialyase activity (PAL) and pre-infection accumulation of 

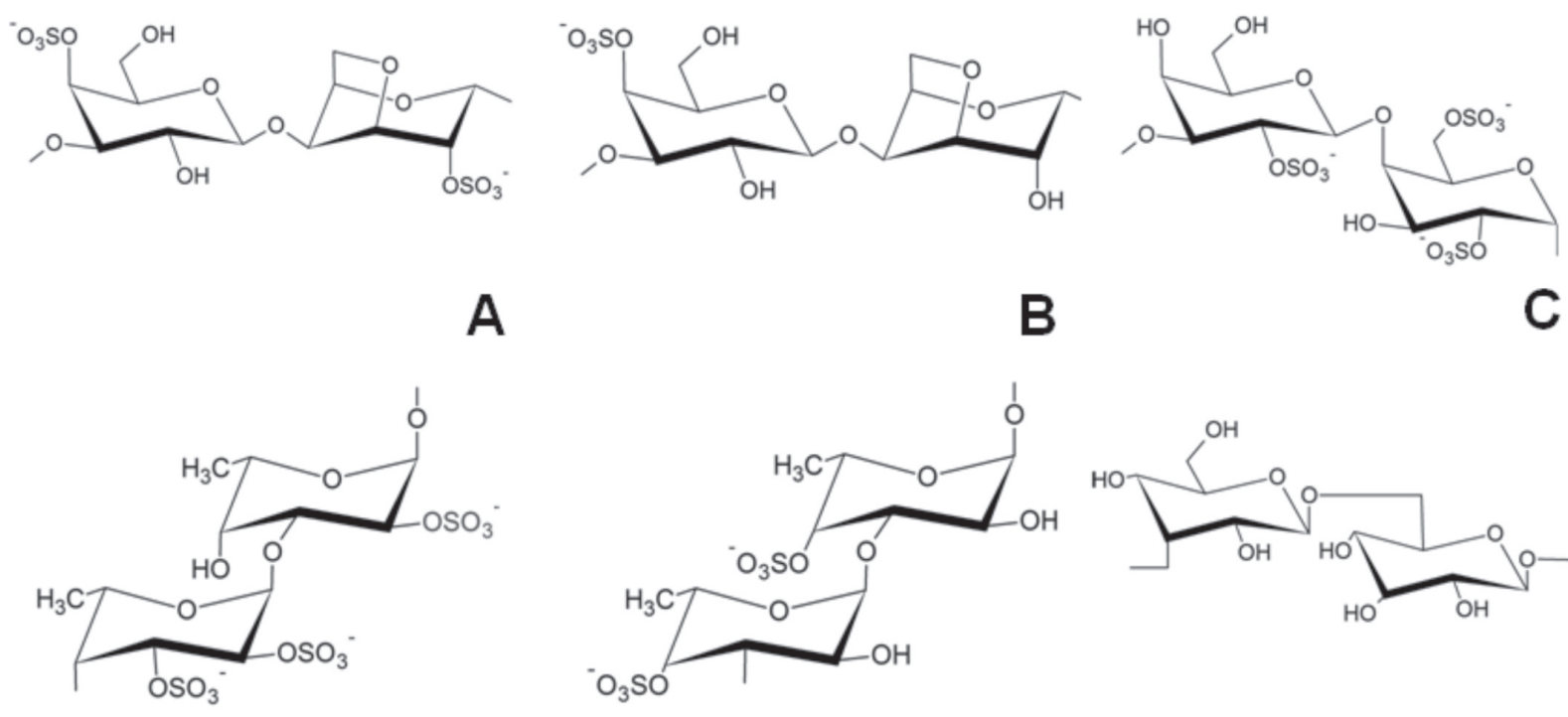

B
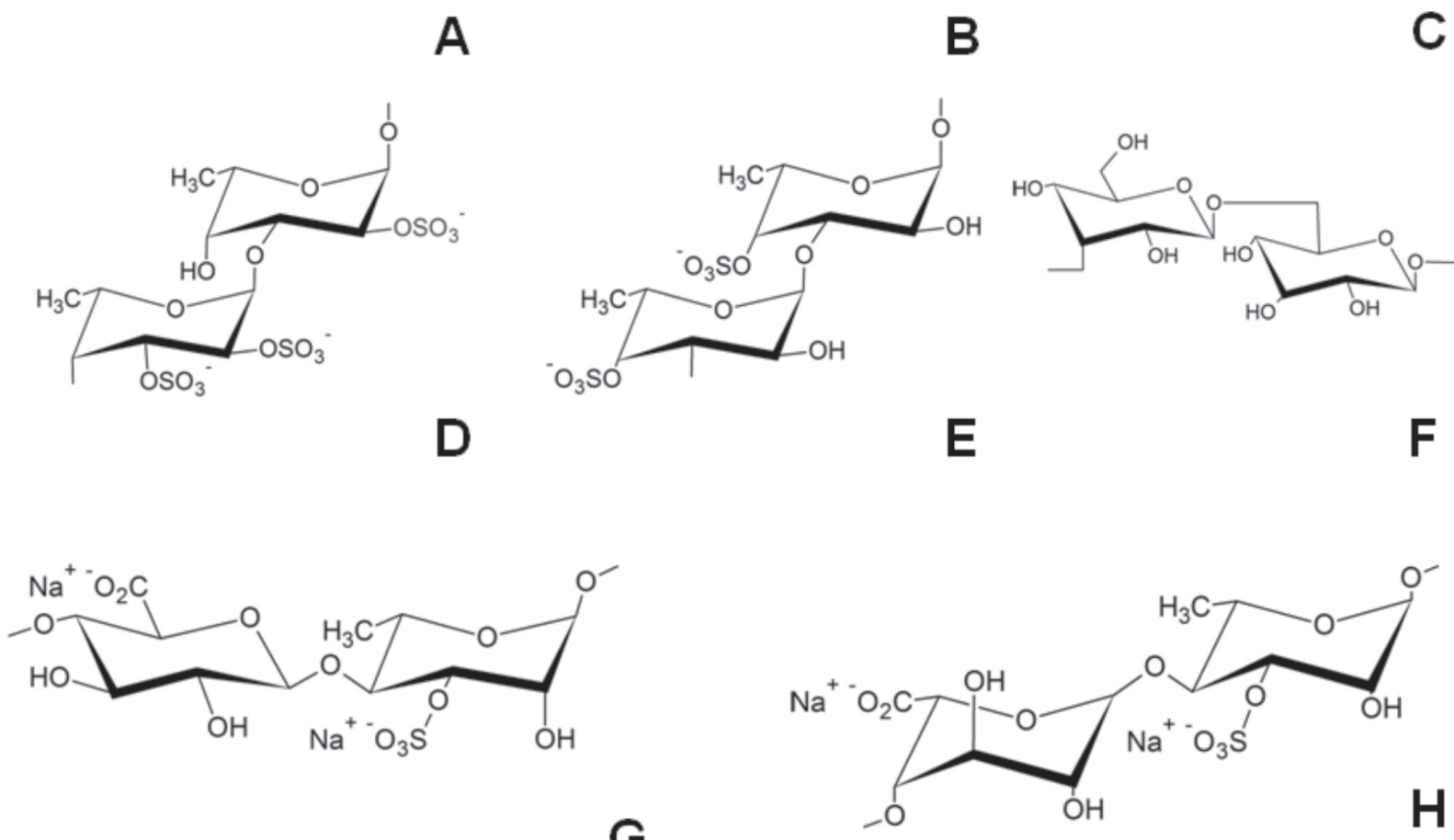

FIGURE 1 - Schematic representation of spatial structure of dimers (repeated units) of different polysaccharides. A. 1-, B. א-, C. $\lambda$-carrageenans; D. Fucans from Ascophyllum nodosum and Fucus spp.; E. Fucan from Ecklonia spp.; F. Laminaran; G. Ulvan type A; H. Ulvan type B.

phenolics, suggesting that these compounds were involved in protection.

The efficiency of the eliciting activity depends on the carrageenan type, its degree of sulfation and the pathogen life style. The pre-treatment of $A$. thaliana with a highly sulfated $\lambda$-carrageenan induced resistance to $S$. sclerotiorum resulting in less foliar damage while the t-carrageenan, with a lower degree of sulfation, increased disease severity (Sangha et al., 2010). Although different types of oligocarrageenans protected tobacco plants similarly against $P$. carotovorum, the $\lambda$ - and 1-oligo-carrageenans were more efficient against $B$. cinerea (Vera et al., 2012). In infiltration assays with tobacco leaf, $\lambda$-carrageenan, with high sulfate content, was more effective in eliciting defenses reaction than the laminaran and an elicitor polysaccharide extracted from Phytophthora megasperma Drechsler. These reactions involved the local production of chitinase and proteinase inhibitors with the effects persisting for a week (Mercier et al., 2001).

Besides the ability to induce systemic resistance, beneficial (biostimulant) effects on plant physiology has been verified with the application of carrageenans. In this way, Castro et al. (2012) concluded that spraying oligocarrageenans weekly at the concentration of $1 \mathrm{mg} / \mathrm{mL}$ stimulated growth, photosynthesis and the basal metabolism of tobacco plants. Based on these studies with oligocarrageenans, patents were registered in several countries, including Brazil, and a product has been commercialized in Chile (Karla) as a biostimulant for eucalyptus (SiriusNatura, 2012).

\section{Fucans}

The algal fucans, frequently denominated fucoidans, are linear or not linear polysaccharides, with a structural characteristic defined by the presence of sulfated L-fucose. The fucose is a hexose deoxy sugar naturally found on the surface of animal and plant cells (Berteau \& Mulloy, 2003). The lack of a hydroxyl group on the carbon at the 6-position (C-6) and the L-configuration are characteristics that distinguish fucose from the other hexoses (Richter, 1996; Nelson \& Cox, 2008). Sulfated fucans are constituted by L-fucose, joined by $\alpha(1 \rightarrow 3)$ glycosidic bond and with 
substitutions on positions 2, 3 and/or 4, depending on algae species (Figure 1) (Berteau \& Mulloy, 2003).

This structural polysaccharide is found in the cell walls of brown algae species (Phaeophyta) such as Ascophyllum nodosum (L.) Le Jolis, Fucus spp. and Ecklonia spp. (Stadnik \& Paulert, 2008). The A. nodosum and Ecklonia spp. that grow in frozen sea waters in the northern hemisphere and South Africa, respectively, have been used as raw material to produce commercial fertilizers and biostimulants for decades in several countries. An extensive list of commercial extracts obtained with these algae can be found in the literature review of Khan et al. (2009). Despite of many statements of algae extracts as biostimulant and phytoprotector activity properties, the bioactive components are not known yet. Besides the phytohormones, the polysaccharides have been considered the possible responsable for their beneficial effects (Stadnik \& Paulert, 2008; Khan et al., 2009).

One of the pioneering studies that shows the effect of $A$. nodosum extracts on plant diseases was reported by Lizzi et al. (1998). In this study, the treatment of plants with alga extract controlled Phytophthora capsici Leonian and Plasmopara viticola (Berkeley and Curtis) Berlese and de Toni in pepper and grapevine, respectively. In association with the control of $P$. capsici, it was observed, in foliar tissues of peeper plant, an increase in peroxidase activity and the synthesis of the phytoalexin capsidiol. For that reason, the authors concluded that the extract of $A$. nodosum acted as a resistance inducer.

Klarzynski etal. (2003) described the eliciting activity of oligosaccharides prepared from enzymatic hydrolysis of sulfated fucan obtained from the brown algae Pelvetia canaliculata (L.) Decaisne and Thuret (Phaeophyta). In tobacco cells suspension, these oligosaccharides induced both early (such as alkalinization of extracellular media and hydrogen peroxide production) and late defense responses (such as an increase in PAL and lipoxygenase activities).

Although fucans are ingredients of most seaweedbased biostimulants and fertilizers, studies about their eliciting activity are still scarce in comparison with other polysaccharides described in the present review.

\section{Laminarans}

The laminarans, also known as laminarins, are reserve polysaccharide found in brown algae, such as Laminaria digitata (Hudson) Lamouroux, that grows in cold waters in the northern hemisphere. It is a linear homopolysaccharide with linkages $\beta(1 \rightarrow 3): \beta(1 \rightarrow 6)$ in a ratio of 3:1 (Figure 1). Another similar polysaccharide is the chrysolaminarin present in phytoplankton and considered one of the most abundant biopolymer in the nature. This water-soluble molecule is composed by glucose units with linkages $\beta(1 \rightarrow 3)$ and $\beta(1 \rightarrow 6)$ in a ratio of $11: 1$. Laminaran has an average polymerization degree of 25 glucose units and three simple ramifications of $\beta$-glucose at the C-6 position (Read et al., 1996; Ménard et al., 2004).
Laminarans are able to stimulate defense reactions in cells suspensions of tobacco (Klarzynski et al., 2000), grapevine (Aziz et al., 2003) and rice (Inui et al., 1997). Typical defense responses include activation of protein kinase, $\mathrm{Ca}^{2+}$ influx, oxidative burst and alkalinization of extracellular media, increase in chitinase and $\beta-1,3-$ glucanase activities and phytoalexins production. When sprayed on tobacco and grapevine plants, laminarans induce phytoalexins accumulation and expression of PR-proteins without triggering hypersensitive response (Klarzynski et al., 2000; Aziz et al., 2003). All this happens because the oligosaccharides obtained from laminaran mimics pathogen attack. They are naturally involved in cellular recognizing mechanisms, in plant-pathogen interactions exogenously (produced by degradation of fungi cell walls) or endogenously (fragmented callose) (Klarzynski et al., 2000).

The biological activity of $\beta$-glucans is possibly the result of its binding with receptors. In fact, a receptor for $\beta-1,3, \beta-1,6$ heptagluconic (chain of $\beta-1,6$ glucose with two $\beta-1,3$ glucose ramifications) was cloned on beans (Mithöfer et al., 2000). There are indicatives that plants cells can discriminate glucans close related as example in rice cells that responded to a pentaglucan (chain of $\beta-1,3$ glucose with a $\beta-1,6$ ramification), obtained from Pyricularia oryzae Cavara, but not to hexaglucan (chain of $\beta-1,6$ glucose with two $\beta-1,3$ ramifications) (Yamaguchi et al., 2000). Nevertheless, tobacco reacts to laminaran, but not to $\beta-1,3, \beta-1,6$ heptaglucan (Klarzynski et al., 2000).

Products based on laminaran such as Iodus and Vacciplant have been commercialized in different countries to control powdery mildew in strawberry and cereals, bacterial fire blight in apple tree and the grey mould in grapevine (Elmer \& Reglinski, 2006; Renard-Merlier et al., 2007; Goëmar, 2012). The product does not have phytoxicity risk and the plant energetic costs of induced resistance are apparently low or inexistent. This natural ingredient is easily biodegradable and has a $\mathrm{LD}_{50}$ higher than $5000 \mathrm{mg} \cdot \mathrm{kg}^{-1}$ of live weight. The laminaran and its oligomers are potent elicitors of plant defenses of dicots (tomato and green bean) and monocots plants (wheat and rice), constituting a suitable alternative tool for disease control in agricultural crops (Klarzynski, 2000; Aziz et al., 2003). In this sense, its application has been recommended for integrated management associated with other methods of disease control (Goëmar, 2012), considering that the reached control level is generally intermediary. Without the induction of cell death, the treatment of grapevine plants with laminaran reduced the infection of $B$. cinerea and $P$. viticola in 55 and $75 \%$, respectively (Aziz et al., 2003).

The structural analyses of laminarans indicated that a minimal length chain and the presence of sulfate residues are determinant factors of eliciting activity. For example, Ménard et al. (2004) demonstrated that laminaran, with eliciting activity in tobacco and $A$. thaliana, after its sulfation, becomes an inducer of the salicylic acid (SA) pathway. 
In tobacco cells suspension, the oxidative burst induced by sulfated laminaran (PS3) was dependent of $\mathrm{Ca}^{2+}$, but partially independent of protein kinases. Cells treated with PS3 or laminaran were completely responsive to a second application of laminaran or PS3, respectively, suggesting two different perception systems. While laminaran induced the expression of ethylene dependent protein, PS3 activated the expression of SA-dependent proteins.

\section{Ulvans}

Ulvans are water-soluble sulfated heteropolysaccharides extracted from the cell walls of green marine macroalgae of genus Ulva, representing from 8 to $29 \%$ of algae dry weight. Ulva, popularly known as "sea lettuce", is widely distributed worldwide and has been used, in small scale, in human food, medicine and agriculture. Otherwise, this genus is frequently involved in ecological problems along the coasts due to its big proliferation in eutrophic environments, called as "green tides", occurring mainly in hot regions of the planet (Cluzet et al., 2004; Wosnitza \& Barrantes, 2005; Lahaye \& Robic, 2007; Paulert et al., 2007 e 2009; Henández-Garibay et al., 2011).

Ulvans are composed by rhamnose (16.8-45.0\%, $\mathrm{p} / \mathrm{p})$, xylose $(2.1-12.0 \%)$, glucose $(0.5-6.4 \%)$, uronic acid (6.5-19.0\%), iduronic acid (1.1-9.1\%) and sulfate (16.0$23.2 \%$ ). Manose and galactose also have been found in ulvans from some Ulva species (Lahaye \& Robic, 2007). These sugars are structurally grouped by two main repeating disaccharides, which are: the ulvabiuronic acid type A ( $\beta$-DGlcA $(1 \rightarrow 4) \alpha$-L-Rha $3 \mathrm{~S} \rightarrow 1)$ and type B $(\alpha$-L-IdoA $(1 \rightarrow 4)$ $\alpha$-L-Rha $3 \mathrm{~S} \rightarrow 1$ ) (Figure 1) (Paulert et al., 2007; Robic et al., 2009). However, the polysaccharide composition can be more complex and is influenced by taxonomical and/or ecophysiological variations (Lahaye \& Robic, 2007).

Bioprospecting studies carried out between 2002 and 2004 evaluated extracts from several macroalgae and macrophytes collected along the Santa Catarina coast in Brazil. As the result, Ulva fasciata Delile was identified as a potential source to provide active compounds for the control of foliar diseases, such as powdery mildew (Erysiphe polygoni DeCandolle) and anthracnose (Colletotrichum lindemuthianum Saccardo and Magnus) on bean (Loffaguen et al., 2004; Abreu, 2005; Abreu et al., 2008). Under greenhouse conditions, spraying of beans with extract of Ulva led to a strong reduction (almost $80 \%$ ) in the number of powdery mildew (E. poligoni) colonies on pre-treated leaves (Jaulneau et al. 2011).

One of the first experiments testing the effect of ulva-extract under field conditions was carried out in 2003 (Loffaguen et al., 2004). In this experiment, monthly sprays of algal extract reduced in 50\% the severity of anthracnose on the highly susceptible bean cultivar IPR Uirapuru. This protective effect was similar to the treatment with strubilurin fungicide.

Further studies with a semi-purified polysaccharide demonstrated that the ulvan is the main elicitor ingredient in extracts of Ulva spp. and can reduce the severity of a broad range of diseases on beans, such as rust (Uromyces appendiculatus (Persoon) Link) (Borsato et al., 2010; Delgado et al., 2013), anthracnose (C. lindemuthianum) (Paulert et al., 2009; Freitas \& Stadnik, 2012) and powdery mildew (E. poligoni) (Jaulneau et al., 2011). In addition, the polissaccharide has shown promising results against other diseases such as Glomerella leaf spot (C. gloeosporioides (Penzig) Penzig and Saccardo) on apple (Araújo et al., 2008; Araújo \& Stadnik, 2013) and powdery mildew (Blumeria graminis (DeCandole) Speer) on wheat and barley (Paulert et al., 2010; Jaulneau et al., 2011). The effects of ulvan in different pathosystems are shown on Table 1.

Greenhouse experiments showed that the foliar application of ulvan reduced anthracnose $(C$. lindemuthianum) severity by $50 \%$ and protected beans for up to nine days after treatment (Schons et al., 2011). Given the fact that ulvan has a systemic effect, but does not inhibit the mycelial growth and conidial germination of fungus in vitro and in vivo, the control has been attributed to induction of plant resistance (Paulert et al., 2009; Freitas \& Stadnik, 2012). However, ulvan has been found to delay the differentiation and melanization of appressoria of $C$. gloeoporioides, while stimulating elongation of germ tubes (Gonçalves \& Stadnik, 2012). Ulvan applied at 1 or 10 $\mathrm{mg} . \mathrm{kg}^{-1}$ also confered an intermediary level of protection against $U$. appendiculatus, reducing the number, diameter and particularly sporulation of rust pustules in susceptible plants. All these effects suggest that mechanisms of resistance operated at latter stages of fungal colonization (Delgado et al., 2013).

Responses to ulvan treatment seem to be multiple and dependent of plant and fungal species involved. According to Cluzet et al. (2004), in alfafa infected with Colletotrichum trifolii Bain and Essary, responses included the biosynthesis of phytoalexins and proteins related with the pathogenesis and showed a maximum elicitation two days after spraying of 500 $\mu \mathrm{g} / \mathrm{mL}$. As expected, ulvan did not cause phytotoxicity and any change in the primary plant metabolism. The eliciting defense activated by ulvan has been reported in other pathosystems such as bean- $U$. appendiculatus (Borsato et al., 2010) and bean-C. lindemuthianum (Freitas \& Stadnik, 2012), where the polysaccharide increased the post-infection activity of glucanase and peroxidase, respectively. Increase in peroxidase activity occured in apple plants at $72 \mathrm{~h}$ after infection with C. gloeosporioides, but not earlier and without affecting glucanase (Araujo \& Stadnik, 2013).

The eliciting defense responses by ulvan in plants seem to be genotype dependent. Borsato et al. (2010) observed that the ulvan spray increased glucanase activity in the moderately susceptible bean cv. Pérola, but not in 'Juriti', a cultivar that is highly susceptible to U. appendiculatus. Again, ulvan increased peroxidase activity on a bean genotype resistant to anthracnose, but not in the susceptible one (Freitas \& Stadnik, 2012).

The resistance induction is frequently associated to priming where the plant treated with the elicitor becomes 
TABLE 1 - Effects of foliar application of ulvan or extracts from Ulva spp. on disease severities in different host-pathogen interactions.

\begin{tabular}{|c|c|c|c|}
\hline Host plant & Pathogen & $\begin{array}{c}\text { Disease } \\
\text { intensities }\end{array}$ & Reference \\
\hline Alfafa & Colletotrichm trifolii & reduced & Cluzet et al. (2004) \\
\hline Apple & Colletotrichum gloeosporioides & reduced & Araújo et al. (2008) \\
\hline \multirow[t]{3}{*}{ Bean } & Colletotrichum lindemuthianum & reduced & Paulert et al. (2009) \\
\hline & Erysiphe polygoni & reduced & Jaulneau et al. (2011) \\
\hline & Uromyces appendiculatus & reduced & Borsato et al. (2010) \\
\hline Cereals & Blumeria graminis & reduced & Paulert et al. (2010) \\
\hline Cucumber & Sphaerotheca fuliginea (Schlechtendal) Pollacci & reduced & Jaulneau et al. (2011) \\
\hline \multirow[t]{4}{*}{ Grapevine } & Erysiphe necator Schweinitz & reduced & Jaulneau et al. (2011) \\
\hline & Plasmopara viticola & reduced & Galvão et al. (2006) \\
\hline & & unaffected & Peruch et al. (2007) \\
\hline & Sphaceloma ampelinum de Bary & reduced & Galvão et al. (2006) \\
\hline Green onions & Alternaria porri (Ellis) Ciferri & reduced & Araújo et al. (2012) \\
\hline \multirow[t]{2}{*}{ Onion } & $\begin{array}{l}\text { Burkholderia cepacia (Palleroni and Holmes) } \\
\text { Yabuuchi }\end{array}$ & unaffected & Wordell et al. (2007) \\
\hline & Peronospora destructor Caspary & unaffected & Wordell et al. (2007) \\
\hline
\end{tabular}

primed and activates defense responses faster and more intensely when exposed to pathogen attack compared to untreated plants (Paulert et al. 2010; Conrath, 2011). The ability of ulvan to induce priming was recently demonstrated. Thus, although ulvan itself did not change the production of hydrogen peroxide, in suspensioncultured wheat or rice cells, its previous addition enhanced the chitin-elicited oxidative burst about five to six folds, and that elicited by chitosan about two folds. In rice cells, the production of hydrogen peroxide elicited by chitin or chitosan was strongly primed by pre-treatment, increasing the burst triggered by the elicitors alone, in 150 and 80 times, respectively (Paulert et al., 2010). On the other hand, spraying of ulvan alone can promote a significant increase of peroxidase and glucanase activities in non-inoculated beans plants (Freitas \& Stadnik, 2012).

Recent studies demonstrated that the signaling pathway of jasmonic acid is involved in the resistance induction by ulvan application (Jaulneau et al., 2010). Thus, this polysaccharide may be efficient against necrotrophic pathogens, because this pathway is generally involved in defense responses against these pathogens (Glazebrook, 2005; Araújo et al., 2012). However, it was also demonstrated that ulvan can control biotrophic (Borsato et al., 2010; Paulert et al., 2010) and hemibiotrophic fungi (Paulert et al., 2009; Freitas \& Stadnik, 2012). The expression of PR-1, a known marker for SA pathway, has been observed after the treatment with ulvan (Cluzet et al., 2004). As consequence, it is possible to argue that the polysaccharide may act in more than one signaling pathway.

Similarly to that reported for other algae species, extracts and/or polysaccharides from Ulva spp. also seem to have stimulant effect on plant physiology. As example, in India, Sridhar \& Rengasamy (2010) used a liquid fertilizer based on Ulva lactuca to improve nutrients absorption, increase the growth, photosynthesis and flowering of marigold (Tagetes erecta L.). On beans, it was observed that the treatment of seeds with ulvan stimulated germination (Paulert et al., 2009).

\section{Concluding remarks}

Although marine seaweeds have been used as biofertilizers since beginning of modern agriculture, only recent studies have focused on the ability of their polysaccharides to enhance plant resistance towards abiotic and biotic stress. In terms of application in agriculture, the algal polysaccharides carrageenans, fucans, laminarans and ulvans have been the most studied ones. The carrageenans are obtained from red algae and have the advantage to have a well-established and sustainable culture system. However, their high market value will probably limit its wide use in plant protection. The fucans, found in the cell walls of brown algae, are constituents of several commercial fertilizers and biostimulants. Studies conducted with fucans have helped to explain some of the beneficial effects of such products on plant physiology. The laminarans are reserve polysaccharides of brown algae, mainly $L$. digitata, which grow in cold waters of the northern hemisphere. These polysaccharides, in a pure form, are currently the most commercially explored to protect plants against a broad spectrum of pathogens. Finally, the ulvans from the cell walls of green seaweeds Ulva spp. open new avenues to obtain poly- and oligosaccharides able to induce plant resistance. The Ulva species are cosmopolitan and abundant algae that have been weakly exploited. Taking into account the promising results and the enormous biochemical diversity of algal polysaccharides, it is likely that they will provide new resistance inducers to be used in agriculture in a near future.

\section{ACKNOWLEDGEMENTS}

The first and second authors thank Conselho Nacional de Desenvolvimento Científico e Tecnológico - 
CNPq and Coordenação de Aperfeiçoamento de Pessoal de Nível Superior - CAPES for the research productivity fellowship and the Ph.D. scholarship, respectively. We are also grateful to Dr. Giorgini Venturieri (CCA-UFSC) for critical reviewing of this manuscript.

\section{REFERENCES}

Abreu GF (2005) Bioprospecção de macroalgas marinhas e plantas aquáticas para o controle da antracnose (Colletotrichum lindemuthianum) do feijoerio (Phaseolus vulgaris L.). M.Sc. Dissertation, Universidade Federal de Santa Catarina. Florianópolis, SC.

Abreu GF, Talamini V, Stadnik MJ (2008) Bioprospecção de macroalgas marinhas e plantas aquáticas para o controle da antracnose do feijoeiro. Summa Phytopathologica 34:78-82.

Araújo L, Stadnik MJ (2013) Cultivar-specific and ulvan-induced resistance of apple plants to Glomerella leaf spot are associated with enhanced activity of peroxidases. Acta Scientiarum Agronomy 35:287-293.

Araújo L, Stadnik MJ, Borsato LC, Valdebenito-Sanhueza RM (2008) Fosfito de potássio e ulvana no controle da mancha foliar da gala em macieira. Tropical Plant Pathology 33:148-152.

Araújo IB, Peruch LAM, Stadnik MJ (2012) Efeito do extrato de alga e da argila silicatada na severidade da alternariose e na produtividade da cebolinha comum (Allium fistulosum L.) Tropical Plant Pathology 37:363-367.

Aziz A, Poinssot B, Daire X, Adrian M, Bézier A, Lambert B, Joubert JM, Pugin A (2003) Laminarin elicits defense responses in grapevine and induces protection against Botrytis cinerea and Plasmopora viticola. Molecular Plant-Microbe Interactions 16:1118-1128.

Berteau O, Mulloy B (2003) Sulfated fucans, fresh perspectives: Structures, functions, and biological properties of sulfated fucans and an overview of enzymes active toward this class of polysaccharide. Glycobiology 13:29-40.

Bixler HJ (1996) Recent developments in manufacturing and marketing carrageenan. Hydrobiologia 326/327:35-57.

Borsato LC, Di Piero RM, Stadnik MJ (2010) Mecanismos de defesa eliciados por ulvana contra Uromyces appendiculatus em três cultivares de feijoeiro. Tropical Plant Pathology 35:318-322.

Castro J, Vera J, González A, Moenne A (2012) Oligo-carrageenans stimulate growth by enhancing photosynthesis, basal metabolism, and cell cycle in tobacco plants (var. Burley). Journal of Plant Growth Regulation 31:173-185.

Cluzet S, Torregrosa C, Jacquet C, Lafitte C, Fournier J, Mercier L, Salamagne S, Briand X, Esquerré-Tugayé MT, Dumas B (2004) Gene expression profiling and protection of Medicago truncatula against a fungal infection in response to an elicitor from green algae Ulva spp. Plant, Cell and Environment 27:917-928.

Conrath U (2011) Molecular aspects of defence priming. Trends in Plant Science 16:524-531.

Craige JS (2011) Seaweed extract stimuli in plant science and agriculture. Journal of Applied Phycology 23:371-393.

De Ruiter GA, Rudolph B (1997) Carrageenan biotechnology. Trends in Food Science and Technology 8:389-395.
Freitas MB, Stadnik MJ (2012) Race-specific and ulvaninduced defense responses in bean (Phaseolus vulgaris) against Colletotrichum lindemuthianum. Physiological and Molecular Plant Pathology 78:8-13.

Delgado ZD, Freitas MB, Stadnik MJ (2013) Effectiveness of saccharin and ulvan as resistance inducers against rust and angular leaf spot in bean plants (Phaseolus vulgaris). Crop Protection 47:67-73.

Elmer PAG, Reglinski T (2006) Biosuppression of Botrytis cinerea in grapes. Plant Pathology 55:155-177.

Galvão S, Stadnik MJ, Peruch LAM, Bruna ED (2006) Avaliação da eficiência de produtos alternativos para o controle do míldio e da antracnose em videira, cultivar Niágara Branca. Agropecuária Catarinense 19:91-93.

Glazebrook J (2005) Contrasting mechanisms of defense against biotrophic and necrotrophic pathogens. Annual Review of Phytopathology 43:205-227.

Goëmar (2012) Iodus 2 Cultures Spécialisées. Stimulateur de défense du fraisier contre l'oïdium du pommier et du poirier contre le feu bactérien Available at: http://www.goemar.com/download/33/2/presentation/ product-data-sheet_33.html. Acessed on: August 1, 2012.

Gonçalves AE, Stadnik MJ (2012) Interferência de ulvana no desenvolvimento e melanização de apressórios de Colletotrichum gloeosporioides. Tropical Plant Pathology 37:431-437.

Hayashi L, de Paula EJ, Chow F (2007) Growth rate and carrageenan analyses in four strains of Kappaphycus alvarezii (Rhodophyta, Gigartinales) farmed in the subtropical waters of São Paulo State, Brazil. Journal of Applied Phycology 19:393-399.

Hayashi L, Santos AA, Faria GSM, Nunes BG, Souza MS, Fonseca ALD, Barreto PLM, Oliveira EC, Bouzon ZL (2011) Kappaphycus alvarezii (Rhodophyta, Areschougiaceae) cultivated in subtropical waters in Southern Brazil. Journal of Applied Phycology 23:337343.

Hernández-Garibay E, Zertuche-González JA, PachecoRuíz I (2011) Isolation and chemical characterization of algal polysaccharides from the green seaweed Ulva clathrata (Roth) C. Agardh. Journal of Applied Phycology 23:537-542.

Inui H, Yamaguchi Y, Hirano S (1997) Elicitor actions of $\mathrm{N}$-acetylchitooligosaccharides and laminarioligosaccharides for chitinase and L-phenylalanine ammonia-lyase induction in rice suspension culture. Bioscience, Biotechnology and Biochemestry 61:975-978.

Jaulneau V, Lafitte C, Jacquet C, Fournier S, Salamagne S, Briand X, Esquerré-Tugayé MT, Dumas B (2010) Ulvan, a sulfated polysaccharide from green algae, activates plant immunity through the jasmonic acid pathway. Journal of Biomedicine and Biotechnology Article ID 525291,11.

Jaulneau V, Lafitte C, Corio-Costet MF, Stadnik MJ, Salamagne S, Briand X, Esquerré-Tugayé MT, Dumas B (2011) An Ulva armoricana extract protects plants against powdery mildew pathonges. European Journal of Plant Pathology 131:393-401.

Khan W, Rayirath UP, Subramanian S, Jithesh MN, Rayorath P, Hodges M, Critchley AT, Craigie JS, Norrie J, Prithiviraj B (2009) Seaweed extracts as biostimulants of plant growth and development. Journal of Plant Growth Regulation 28:386-399.

Klarzynski O, Plesse B, Joubert JM, Yvin JC, Kopp M, Kloareg B, Fritig B (2000) Linear beta-1,3 glucans are elicitors of defense responses in tobacco. Plant Physiology 124:1027-1037. 
Klarzynski O, Descamps V, Plesse B, Yvin JC, Kloareg B, Fritig B (2003) Sulfated fucan oligosaccharides elicit defense responses in tobacco and local and systemic resistance against tobacco mosaic virus. Molecular Plant-Microbe Interactions 16:115-122.

Kloareg B, Quatrano RS (1988) Structure of the cell walls of marine algae and ecophysiological functions of the matrix polysaccharides. Oceanography and Marine Biology Annual Review 26:259-315.

Kulik MM (1995) The potential for using cyanobacteria (blue-green algae) and algae in the biological control of plant pathogenic bacteria and fungi. European Journal of Plant Pathology 101:585-599.

Lahaye M, Robic A (2007) Structure and functional properties of ulvan, a polysaccharide from green seaweeds. Biomacromolecules 8:1765-1774.

Lizzi Y, Coulomb C, Polian C, Coulomb PJ, Coulomb PO (1998). L'algue face au Mildiou quel avenir? Phytoma 508:29-30.

Loffaguen JC, Hartmann OEL, Talamini V, Stadnik MJ (2004) Extratos naturais no controle da antracnose e na produtividade do feijoeiro. Fitopatologia Brasileira 29(Suppl.):107.

Mercier L, Lafitte C, Borderies G, Briand X, Esquerré-Tugayé M-T, Fournier J (2001) The algal polysaccharide carrageenans can act as an elicitor of plant defence. New Phytologist 149:43-51.

Ménard R, Alban S, de Ruffray P, Jamois F, Franz G, Fritig B, Yvin J-C, Kauffmann S (2004) $\beta-1,3$ glucan sulfate, but not $\beta-1,3$ glucan, induces the salicylic acid signaling pathway in tobacco and Arabidopsis. Plant Cell 16:3020-3032.

Mithöfer A, Fliegmann J, Neuhaus-Url G, Schwarz H, Ebel J (2000) The hepta-beta-glucoside elicitor-binding proteins from legumes represent a putative receptor family. Biological Chemistry 381:705-713.

Nelson DL, Cox MM (2008) Lehninger's Principles of Biochemistry. New York, NY, USA. Freeman and Company.

Patier P, Potin P, Rochas C, Kloareg B, Yvin JC, Liénart Y (1995) Free or silica-bound oligokappa-carrageenans elicit laminarase activity in Rubus cells and protoplasts. Plant Science 110:27-35.

Paulert R, Smânia Júnior A, Stadnik MJ, Pizzolato MG (2007) Antimicrobial properties of extracts from the green seaweed Ulva fasciata Delile against pathogenic bacteria and fungi. Algological Studies 123:123-130.

Paulert R, Talamini V, Cassolato JEF, Duarte MER, Noseda MD, Smania Júnior A, Stadnik MJ (2009) Effects of sulfated polysaccharide and alcoholic extracts from green seaweed Ulva fasciata on anthracnose severity and growth of common bean (Phaseolus vulgaris L.). Journal of Plant Diseases and Protection 116:263-270.

Paulert R, Ebbinghaus D, Urlass C, Moerschbacher BM (2010) Priming of the oxidative burst in rice and wheat cell cultures by ulvan, a polysaccharide from green macroalgae, and enhanced resistance against powdery mildew in wheat and barley plants. Plant Pathology 59:634-642.
Peruch LAM, Medeiros AM, Bruna ED, Stadnik MJ (2007) Biomassa cítrica, extrato de algas, calda bordalesa e fosfitos no controle do míldio da videira, cv. Niágara Branca. Revista de Ciências Agroveterinárias 6:143-148.

Read SM, Currie G, Bacic A (1996) Analysis of the structural heterogeneity of laminarin by electrospray-ionisation-mass spectrometry. Carbohydrate Research 281:187-201.

Renard-Merlier D, Randoux B, Nowak E, Farcy F, Durand R, Reignault P (2007) Iodus 40, salicylic acid, heptanoyl salicylic acid and trehalose exhibit different efficacies and defense targets during a wheat/powdery mildew interaction. Phytochemistry 68:1156-1164.

Richter G (1996) Biochemie der Pflanzen. Stuttgart, Germany. Georg Thieme Verlag.

Robic A, Gaillard C, Sassi JF, Lerat Y, Lahaye M (2009) Ultrastructure of ulvan: A polysaccharide from green seaweed. Biopolymers 91:652-664.

Sangha JS, Ravichandran S, Prithiviraj K, Critchley AT, Prithiviraj B (2010) Sulfated macroalgal polysaccharides $\lambda$-carrageenan and 1-carrageenan differentially alter Arabidopsis thaliana resistance to Sclerotinia sclerotiorum. Physiological and Molecular Plant Pathology 75:38-45.

Schons RF, Freitas MB, Stadnik MJ (2011) Durabilidade da resistência induzida por ulvana e efeito da concentração de inóculo no controle da antracnose do feijão. Bioscience Journal 27:544-551.

SiriusNatura (2012) Estimulante foliar orgânico. Available at: http:// www.siriusnatura.cl/web/?page_id=5. Accessed on August 1, 2012.

Sridhar A, Rengasamy R (2010) Effect of seaweed liquid fertilizer on the growth, biochemical constituintes and yield of Tagetes erecta, under field trial. Journal of Phytology 2:61-68.

Stadnik MJ, Paulert R (2008) Uso de macroalgas marinhas na agricultura. In: XI Congresso Brasileiro de Ficologia. Rio de Janeiro, RJ. Museu Nacional do Rio de Janeiro. pp. 267-279.

Vera J, Castro J, Contreras RA, González A, Moenne A (2012) Oligo-carrageenans induce a long-term and broad-range protection against pathogens in tobacco plants (var. Xanthi). Physiological and Molecular Plant Pathology 79:31-39.

Whitfield C (2006) Biosynthesis and assembly of capsular polysaccharides in Escherichia coli. Annual Review of Biochemistry 75:39-68.

Wordell Filho JA, Martins DA, Stadnik MJ (2007) Aplicação foliar de tratamentos para o controle do míldio e da podridão-deescamas de bulbos de cebola. Horticultura Brasileira 25:544-549.

Wosnitza TMA, Barrantes JG (2005) Utilization of seaweed Ulva sp. in Paracas Bay (Peru): Experimenting with compost. Journal of Applied Phycology 18:27-31.

Yamaguchi T, Yamada A, Hong N, Ogawa T, Ishii T, Shibuya N (2000) Differences in the recognition of glucan elicitor signals between rice and soybean: Beta-glucan fragments from the rice blast disease fungus Pyricularia oryzae that elicit phytoalexin biosynthesis in suspension-cultured rice cells. Plant Cell 12:817-826. 